\title{
Infrared Thermography as a Prognostic Livestock Agrotechnology: A Critique
}

\section{Akbar Nikkhah ${ }^{*}$ \\ Chief Highly Distinguished Professor, Department of Animal Sciences, Faculty of Agricultural Sciences, University of Zanjan, Zanjan, Iran}

*Corresponding author: Akbar Nikkhah, Chief Highly Distinguished Professor, Department of Animal Sciences, Faculty of Agricultural Sciences, University of Zanjan, Zanjan 313-45195, Iran, Tel: +98-241-5152801; Fax: +98-241-5283202; E-mail: anikkha@yahoo.com

Rec date: Nov 20, 2014; Acc date: Nov 22, 2014; Pub date: Nov 24, 2014

Copyright: $\odot 2014$ Nikkhah A. This is an open-access article distributed under the terms of the Creative Commons Attribution License, which permits unrestricted use, distribution, and reproduction in any medium, provided the original author and source are credited.

\section{Editorial}

The objective of this article is to critically and pragmatically evaluate the pros and cons of Infrared thermography (IRT) as a postmodern prognostic livestock agrotechnology. The IRT detects thermal radiation from objects [1]. This technology offers a noninvasive noncontact management tool for farmers to detect circadian and weekly fluctuations as well as significant short- and long-term changes in skin temperature from different tissues [2-4]. Such temperature changes would be considered as an indicator of metabolic alterations in underlying tissues $[5,6]$.

The temperature of any surface including body depends closely on blood flow and tissue metabolism rate $[1,7]$. Therefore, the potential exists to monitor and quantify the physiological and health states of underlying tissues by measuring skin temperature and its circadian, day-to-day, seasonal, and circannual oscillations [8]. The IRT may be utilized to diagnose inflammatory conditions, such as sole abscesses and laminitis in horses and dairy cows $[1,3,4,6]$, hot-iron and freeze branding in cattle [9], whole body physiological state using eye temperature in equine and ruminants [10], and mastitis in dairy cows, sheep and camel [11-14]. For instance, feet soles suffering from subclinical laminitis appear soft and warm well before other clinical and severe signs (e.g., color changes, lesions, hemorrhages, and ulcers) appear [6]. As such, IRT could potentially be used for early detection and quantification of inflammation. If capable so, IRT may help to early diagnose the many syndromes and diseases in farm animals before their devastating health and economical consequences occur. This would mean a prognostic function for IRT in modern and postmodern livestock agrotechnology. Such a capability would allow interventions to prevent and attenuate unhealthy conditions. However, such solid and consistent applications will yet need to be realized on a global scale, which necessitates considerably more extensive and longitudinal studies.

Images of IRT are taken using hand-held portable infrared cameras that are increasingly advancing in shape and function. Cameras must be calibrated to ambient temperature and absorptive conditions on each sampling day. To minimize effects of environmental noises on thermal data, all images must be scanned within the same environmental conditions and at the same distance from the surface of interest. For example, hoof and skin surfaces must be free of debris and humidity before images are taken. Afterwards, images are captured using a fixed control temperature range according to the range of temperature in the surface of interest. Usually, the continuous camera output for each case (i.e., animal, poultry) for each collection time is saved (e.g., for 5-10 s) onto a digital video with particular numbers of individual frames (e.g., 10-50) per s of recording. Single digitized image is captured as a still and saved into the grey scale graphics file prior to analysis using image processing softwares. Images are calibrated by relating each of the shades of grey on the digitized image to a specific temperature for all pixels. It is important to remove any outlier maximum temperatures form extraneous particles. Also, depending on the surface of interest, a control skin area should be traced for within-area and within-animal corrections. For this, the maximum relative temperature of the control area must be deducted from that of the target surface to minimize variability and allow interanimal comparisons [6].

Generally, IRT is a noninvasive tool that poses minimum stress to livestock and has the ability to diagnose major diseases $[15,16]$. This uniqueness attracts greater attention in animal welfare as an increasing concern for the global industry $[15,17]$. Recently, more work has been conducted to get the industry better acquainted with instrumentation and applications of IRT, particularly in equine production. All in all, effective education of IRT's SciTech including advantages and disadvantages to producers and investors will enable practices and interventions towards its efficient and compelling applications in future $[7,8]$.

The high cost may be a major source of discouragement that could only be dealt with through interdisciplinary education. Although rising research evidence suggests that IRT reliably monitors skin temperature changes due to inflammatory or abnormal tissue and cell physiological conditions, its forecasting capability long before clinical symptoms occur (i.e., early enough prognosis) remains unrevealed. Artifacts are of concern as well. These unreal and unrepresentative values stem from the several interfering factors that affect the extent and rate of thermal radiations detected by the camera. In fact, the thermal radiation specifically coming from the surface of interest, and not from other ambient sources, must be specifiable. Moreover, IRT can only determine possible changes in the skin temperature, but informs little on causes. This implies that other management tools must be used alongside IRT for accurate measurements, effective prevention, and working treatments. Non-disease factors influencing skin temperatures must be specified and quantified for IRT to gain global on-farm merit for any future recommendation as a prognostic livestock agrotechnology.

\section{Acknowledgment}

The Iranian Ministry of Science Research \& Technology, National Elite Foundation, and University of Zanjan are gratefully thanked for supporting the author's global programs of optimizing science edification in the new millennium.

\section{References}

1. Eddy AL, van Hoogmoed LM, Snyder JR (2001) Review: The role of thermography in the management of equine lameness. Vet. J 162: 172-181. 
Citation: Nikkhah A (2015) Infrared Thermography as a Prognostic Livestock Agrotechnology: A Critique. Agrotechnol 4: e112. doi: 10.4172/2168-9881.1000e112

Page 2 of 2

2. Schaefer AL, Cook N, Tessaro SV, Deregt D, Desroches G, et al. (2004) Early detection and prediction of infection using infrared thermography. Can J Anim Sci 84: 73-80.

3. Nikkhah A, Safari H (2012) Infrared thermography to timely diagnose, prevent and monitor equine laminitis. Proceedings of First National Congress on Pure Persian Horses, Iran: 230-234.

4. Nikkhah A, Safari H (2012) Infrared thermography to optimize equine health physiology and management. Proceedings of First National Congress on Pure Persian Horses, Iran: 235-241.

5. Nikkhah A, Safari H (2013) Infrared thermography for effective diseases prevention and management and welfared poultry production. Proceedings of the 2nd Scientific \& Specialized Conference on Iranian Poultry Industry, Iran.

6. Nikkhah A, Plaizier JC, Einarson MC, Berry RJ, Scott SL, et al. (2005) Infrared thermography and visual examination of hooves of dairy cows in two stages of lactation. J Dairy Sci 88: 2749-2753.

7. Nikkhah A, Safari H (2013) Infrared thermography capability in effective laminitis prevention and management in dairy cows. The 8th Convention of Iranian Veterinary Clinicians \& The 2nd Symposium on Ruminant Lameness and its Economical Significance on Animal Products, Iran.

8. Nikkhah A, Safari H (2013) Infrared thermography technology: Economical management of modern animal industries. The 8th Convention of Iranian Veterinary Clinicians \& The 2nd Symposium on Ruminant Lameness and its Economical Significance on Animal Products, Iran.
9. Schwartzkopf-Genswein KS, Stookey JM (1997) The use of infrared thermography to assess inflammation associated with hot-iron and freeze branding in cattle. Can J Anim Sci 77: 577-583.

10. Johnson S, Roa S, Hussey S, Morley P, Traub-Dargatz J (2011) Thermographic eye temperature as an index to body temperature in ponies. J. Eq. Vet Sci 31: 63-66.

11. Hovinen MJ, Siivonen S, Taponen L, Hänninen M, Pastell AM, et al. (2008) Detection of clinical mastitis with the help of a thermal camera. J. Dairy Sci 91: 4592-4598.

12. Polat B, Colak A, Cengiz M, Yanmaz LE, Oral H, et al. (2010) Sensitivity and specificity of infrared thermography in detection of subclinical mastitis in dairy cows. J Dairy Sci 93: 3525-3532.

13. Martinsa RFS, Paimb TDP, Cardosoa CDA, Dallagoa BSL, Meloa CBD, et al. (2013) Mastitis detection in sheep by infrared thermography. Res Vet Sci 94: $722-724$.

14. Emad M, Samaraa, Ayadia M, Aljumaaha RS (2014) Feasibility of utilising an infrared-thermographic technique for early detection of subclinical mastitis in dairy camels (Camelus dromedarius). J Dairy Res 81: 38-45.

15. Stewart M, Webster J, Schaefer A, Cook N, Scott S (2005) Infrared thermography as a non-invasive tool to study animal welfare. Anim Welf 14: 319-325.

16. Meola C, Carlomagno (2004) Recent advances in the use of infrared thermography. Meas Sci Technol 15: R27-R58.

17. Yanmaz LE, Zafer O, Dogan E (2007) Instrumentation of themography and its applications in horses. J Anim Vet Adv 6: 858-862. 